\title{
耐候性鋼および鉄文化財における耐食性とさびの構造†
}

長 野 博 夫* 山下正人** 鈴 木 重 夫***

\section{Corrosion Resistance and Rust Structure of Weathering Steels and Iron Antiquities}

by

\author{
Hiroo Nagano*, Masato Yamashita** and Shigeo Suzuki***
}

In this investigation, the structure of a rust layer on iron and steel materials exposed to atmospheric and soil environments for a long peroid, up to approximately 1600 years, is discussed. It is found that the rust constituents change with exposure time. The rust layer transforms and stabilizes to $\alpha-\mathrm{FeOOH}$. It can be pointed out that the structure of a rust layer suggests the environmental condition in which the materials have been preserved.

Key words : Rust layer, $\mathrm{FeOOH}$, Iron and steel materials, Antique materials, Long-term exposure

\section{1 緒言}

鉄は強い，硬い，加工がしやすい，高温にも耐えられ る, 比較的安価である等の理由でほとんどあらゆる分野 で使用されている。建物, 橋梁, 鉄道, 乗り物, 各種プ ラント等などである。 また，古くは武器，美術品等にも 使用されている. しかし, 鉄はさびて, 消失していくこ とから，鉄の利用の歴史はさびとの戦いであると言って も過言ではない. その結果, ステンレス鋼の発明, アル ミニウムバルブメタルのチタン, ジルコニウム, タンタ ルの活用, 表面処理技術としてのめっき, 有機防食塗装 の発達をもたらした：また，鉄自身においても微量の $\mathrm{Cu}, \mathrm{P}, \mathrm{Ni}, \mathrm{Cr}$ 等を鋼中に添加した低合金である耐候性 鋼においては，防食効果を発揮するさび層を形成するこ とにより，通常の鋼より数段酎候性が優れる事が実証さ れている.

さらに，古代から保存されている，或いは最近見いだ され，発掘された鉄製の文化財はさび層に覆われている. 金属文化財のさび層の厚さ，組成はその文化財の年代と 密接な関係にある。 また，鉄構造物の数百年一数千年に わたる寿命を推定するためには Natural Analogue と称 して文化財の長期耐食性を研究することが有効である (Fig. 1).

本報はかかる観点において，さびの構造と耐食性，さ びの構造変化と鉄製品の年代について報告する.

\section{2 さびの生成機構}

鉄の腐食反応は局部電池を形成して進行する. その電 池はアノード反応が陽極, カソード反応が陰極で進行す る.

酸性溶液中の反応:

$$
\text { アノード反応 } \mathrm{Fe} \rightarrow \mathrm{Fe}^{2+}+2 \mathrm{e}^{-}
$$

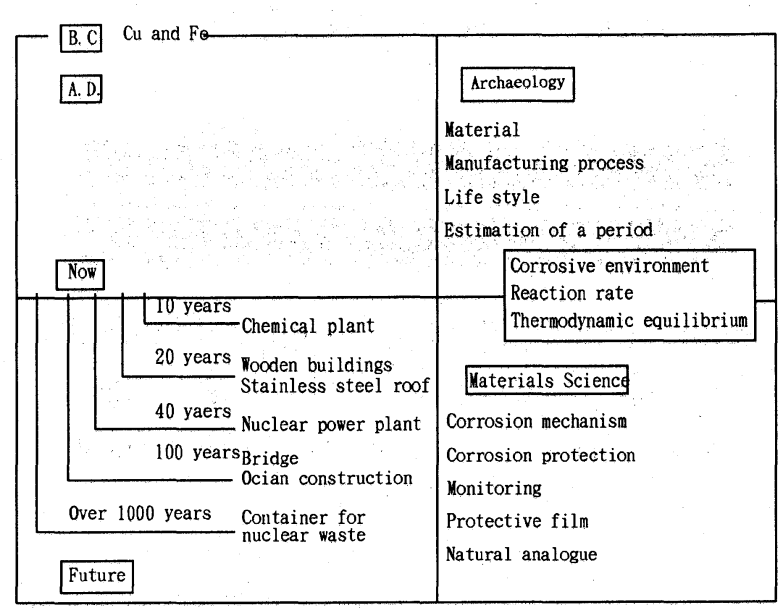

Fig. 1. Contact between metallurgical archaeology and materials science.

$$
\begin{array}{ll}
\text { カソード反応 } & 2 \mathrm{H}^{+}+2 \mathrm{e}^{-} \rightarrow \mathrm{H}_{2} \\
\text { 総括反応 } & \mathrm{Fe}+2 \mathrm{H}^{+} \rightarrow \mathrm{Fe}^{2+}+\mathrm{H}_{2}
\end{array}
$$

中性およびアルカリ溶液中の反応：

$$
\begin{aligned}
& \text { アノード反応 } \mathrm{Fe} \rightarrow \mathrm{Fe}^{2+}+2 \mathrm{e}^{-} \\
& \text {カソード反応 } 2 \mathrm{H}_{2} \mathrm{O}+\mathrm{O}_{2}+4 \mathrm{e}^{-} \\
& \rightarrow 4 \mathrm{OH}^{-} \\
& \text {総括反応 } \\
& 2 \mathrm{Fe}+2 \mathrm{H}_{2} \mathrm{O}+\mathrm{O}_{2} \\
& \rightarrow 2 \mathrm{Fe}^{2+}+4 \mathrm{OH}^{-} \\
& \rightarrow 2 \mathrm{Fe}(\mathrm{OH})_{2}
\end{aligned}
$$

Fig. 2 に鉄のアノード溶解曲線（実線）と酸素のカソ 一ド還元曲線（点線）を示す. 実線と点線とが交わる点 の電位（腐食電位）での電流密度（腐食電流密度）で腐 食が進行する，電位が上昇する事により鉄の腐食は活性 態 $\rightarrow$ 不働態 $\rightarrow$ 過不働態となる，不働態で鉄の腐食が最小

$†$ 原稿受理 平成 7 年 2 月 8 日 Received Feb. 8, 1995

* 正会員 住友金属工業(株)総合研究開発セン夕 $=660$ 尼崎市扶桑町, Res. and Development Center, Sumitomo Metal Ind., Ltd., Fusocho, Amagasaki, 660

** 正会員 住友金属工業(株)鉄鋼技術研究所 T660 尼崎市扶桑町, Iron and Steel Res. Lab., Sumitomo Metal Ind. Ltd., Fusocho, Amagasaki, 660

*** (株)京都科学 開発センター ₹619-02 京都府相楽郡木津町兜台, Development Center, Kyoto Kagaku Ltd., Kizucho, Kyoto, 619-02 


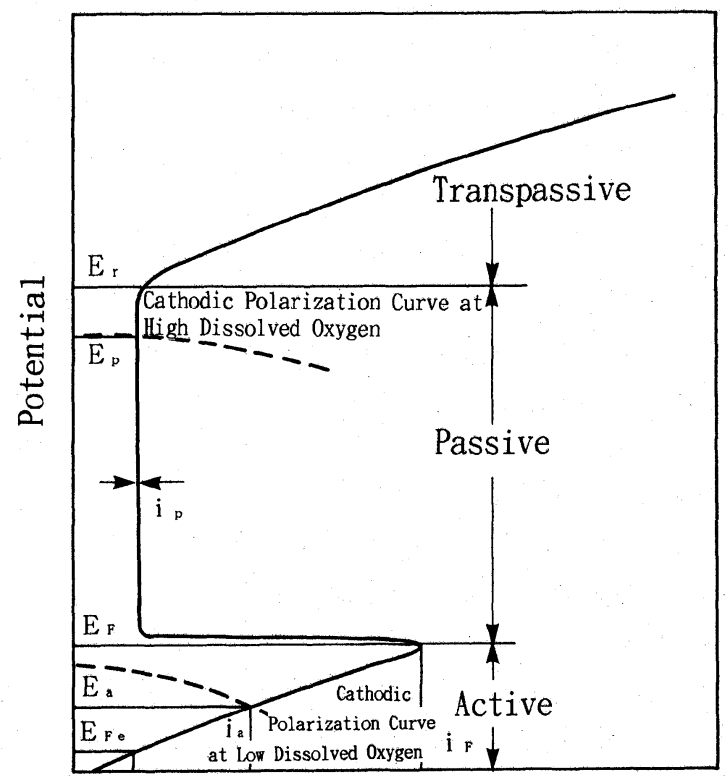

Current Density

$E_{\mathrm{Fe}}$ Standard electrode potential of $\mathrm{Fe}$.

$E_{a}$ : Corrosion potential at active region.

$i_{a}$ : Corrosion current at active region.

$E_{f}:$ Passivation potential.

$i_{f}$ : Passivation current.

$E_{p}$ : Corrosion potential at passive region.

$i_{p}:$ Passive current.

$E_{r}$ : Passive-active transition potential.

Fig. 2. Schematic illustration of anodic polarization curve of $\mathrm{Fe}$ in neutral solution.

となる.活性態では鉄の表面は裸か $\mathrm{Fe}(\mathrm{OH})_{2}$ で覆われ， 不働態では $\mathrm{Fe}(\mathrm{OH})_{3}, \mathrm{FeOOH}$ 或いは $\mathrm{Fe}_{2} \mathrm{O}_{3}$ で覆われて いる，過不働態では鉄は $\mathrm{FeO}_{4}{ }^{2-}$ として溶出する.

最近の文献によれば不働態皮膜は $\mathrm{FeOOH} と \gamma$ $-\mathrm{Fe}_{2} \mathrm{O}_{3}$ の 2 層か $\mathrm{FeOOH}$ の単層から成り立っている.

$\mathrm{FeOOH} に は \alpha-, \beta-, \gamma-, \delta-\mathrm{FeOOH}$ の 4 種類がある. $\alpha, \gamma$ 型は通常のさびに一般に見られるが， $\beta$ 型は腐食 環境中に $\mathrm{Cl}^{-}$イオンがかなり含有されているときに生 成する.

三沢は鉄酸化物の標準生成自由エネルギーを

$$
\Delta \mathrm{F}_{\mathrm{f}}^{0} \alpha_{\text {-Feоон }}=-118.6 \mathrm{kcal} / \mathrm{mole}
$$$$
\Delta \mathrm{F}_{\mathrm{f}}^{0} \gamma_{\text {- Fеоон }}=-112.5 \mathrm{kcal} / \mathrm{mole}
$$

と計算して, 不働態皮膜の主成分をなす鉄酸化物の電 位 - $\mathrm{pH}$ 図を溶出鉄㧍よび鉄化合物イオンの活量を $10^{-3}$ として作成した (Fig. 3). 通常の鉄の腐食電位を考慮す ると酸性溶液では $\alpha-\mathrm{FeOOH}$ が生成しやすく, 中性環 境では $\alpha-\mathrm{FeOOH}$ および $\mathrm{Fe}_{3} \mathrm{O}_{4}$ が生成しやすい.また， アルカリ性環境では $\mathrm{Fe}(\mathrm{OH})_{2}$ が比較的安定で, 酸化さ れると $\mathrm{Fe}_{3} \mathrm{O}_{4}$ 或いは $\alpha-\mathrm{FeOOH}$ となる. しかし, 実際 の腐食生成物中には $\gamma-\mathrm{FeOOH}$ がよく見いだされる.

これは腐食生成物が熱力学的安定性のみならず反応速度, あるいは他の環境因子の影響を受けるためと説明されて いる.

すなわち，大気或いは土中において生ずる鉄さびの生 成，鉄の腐食は環境的，材料的，経時的にも複雑であり，
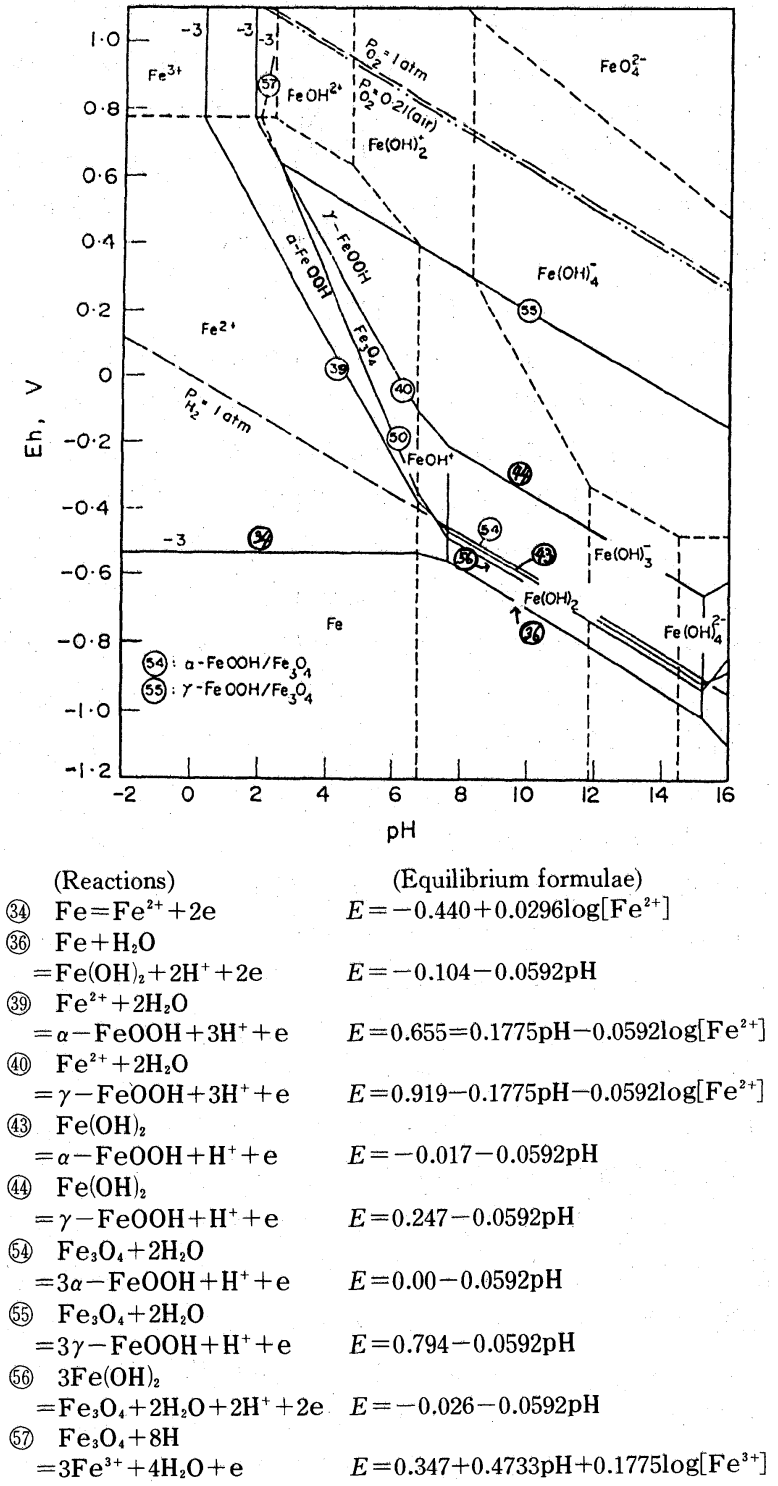

Fig. 3. Potential-pH diagram for $\mathrm{Fe}-\mathrm{H}_{2} \mathrm{O}$ system at activity of dissolved ion species of $10^{-3}, 25^{\circ} \mathrm{C}^{2}$.

また，さびの生成には酸化状態が変化しないさびの相変 態も関与する。

耐食性に関しては, 使用される環境, 例えば大気, 地 下，水，海水中において鉄に生成するさびの結晶構造, 厚さ, 密度などが異なり, 腐食速度も大気, 地下中で $0.01 \mathrm{~mm} / \mathrm{y}$ 前後, 静止水, 静止海水中で $0.1 \mathrm{~mm} / \mathrm{y}$ 前 後となる。

\section{3 さび構成化合物の定量方法}

本研究では数十年間大気暴露試験を行った耐候性鋼 (JIS G 3114，3125) および長期間大気中あるいは土中に 存在していた鉄文化財のさび層の構成化合物を定量し， 鉄さびの長期構造変化を議論する. 定量のために，カッ ターナイフにて採取したさびを粉砕し粉末試料を作製し た。得られた粉末試料について, $\mathrm{KCl}$ 内部標準法を利 用した X 線回折法によりさび構成鉄化合物の定量分析 を行った，装置は理学電機(株)製 RU200 型によりター ゲットとして Co を用い，電圧一電流を $30 \mathrm{kV}-100 \mathrm{~mA}$ とし走查速度 $2 \% \mathrm{~min}$.の条件による粉末法で行った。 
さび層構成鉄化合物の定量は, 一定量の $\mathrm{KCl}$ 粉末を あらかじめさび粉末中に混合し，作成した検量線を用い て $\alpha-\mathrm{FeOOH}$ の $24.7^{\circ}(011)$ 反射, $\gamma-\mathrm{FeOOH} の 16.4^{\circ}(020)$ 反射, $\beta-\mathrm{FeOOH}$ の $13.9^{\circ}(110)$ 反射, $\mathrm{Fe}_{3} \mathrm{O}_{4}$ の $41.4^{\circ}(311)$ 反射の強度を $\mathrm{KCl}$ の $33.0^{\circ} /(020)$ 反射の強度と 比較することにより行った。

\section{4 耐候性鋼のさび}

$\mathrm{Cr}, \mathrm{Cu}, \mathrm{P}$ 等耐候性向上元素を少量含有する低合金 鋼である耐候性鋼は，普通鋼の約 2 倍の耐候性を有して おり, 大気腐食環境中の各種構造用材料として広く用い られている．耐候性鋼は大気中で自然に保護的なさび層 いわゆる安定さび層を形成するため耐候性が向上する.

長期大気暴露試験による耐候性鋼と普通鋼の腐食量の 経時変化を比較すると, 耐候性鋼は数年を経過すれば腐 食速度が減少し, 10 年以上の期間で安定さび層が形成 し始め, ほぼ一定の低い腐食速度となる，最終的に形成 した安定さび層は緻密で有効元素の濃縮したさび層であ り，黒色系の落ち着いた色となる，一方，普通鋼では， 10 年以上を経過しても腐食速度の低減は少ない.

耐候性鋼の安定さび層形成過程について, 1970 年代 に主として数年間の暴露試験結果を基に活発に議論され てきた. 安定さび層は, 外層および内層の二層構造を有 しており，内層が防食性を有するさび層であると考えら れている. 三沢らは, 結合水を多く含む非晶質オキシ水 酸化鉄が緻密で密着性良好な安定さび層であることを指 摘している. 岡田ら ${ }^{21,22)}$ Kihira ら'は, 耐候性向上元素の 濃化した緻密で X 線的に非晶質な内層のスピネル型酸 化物層が耐食性に寄与していると考えている. 多くの調 査により , さび層の主要な結晶性構成物質は $\alpha$ -FeOOH および $\gamma$-FeOOH であると言えるであろう。 また上述のようにその他非晶質さび物質も含まれている.

主要なさび層構成物質である $\alpha-\mathrm{FeOOH}, \gamma-\mathrm{FeOOH}$, $\mathrm{X}$ 線的に同定できない非晶質物質それぞれの質量割合 の長期経年変化を Fig. 4 に に示す. 耐候性鋼のさび層構成 物質の割合は暴露期間の経過とともに図中の 3 領域を移 動する。.すなわち, 暴露数年以内の初期には $\gamma$

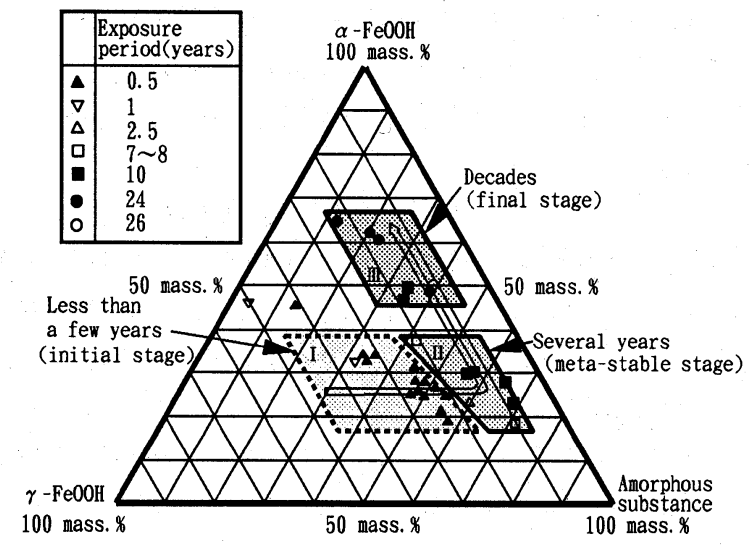

Fig. 4. The exposure-time dependence of the fractions of rust constituents formed on low-alloy: steels by atmospheric corrosion. The fraction changes along an open arrow ${ }^{25)}$.
$-\mathrm{FeOOH}$ の量が多く, 数年〜10 年の暴露期間では $\mathrm{X}$ 線 的非晶質物質が多くなり, さらに 10 20 年以上の大気 暴露を行うと $\alpha-\mathrm{FeOOH}$ が主成分となる。この結果よ り，1970 年代に議論された非晶質さび層は, この長期 相変態の中間段階であると考えられる.このように, 暴 露期間とともに, $\gamma-\mathrm{FeOOH}$ から $\alpha-\mathrm{FeOOH}$ へ相変態 することに着目し， $\alpha-\mathrm{FeOOH}$ の $\gamma-\mathrm{FeOOH}$ に対する 質量比 $(\alpha / \gamma)$ を暴露期間に対し整理すると Fig. 5 のよう になる。暴露期間とともにほぼ直線的に $\alpha / \gamma$ が増加す ることがわかる.このことより， $\alpha / \gamma$ から鋼材の使用 年数が推定が可能であることが指摘できる. Fig. 6 に示 すように, このようなさび層の相変態とともに $\alpha / \gamma$ が 増加し，耐候性鋼の腐食速度は低下する。

四半世紀以上の長期大気暴露により十分安定化し高い 防食性を有するさび層について最近詳細な調査がなされ ている. 長期暴露後の安定さび層は内層と外層からなる 二層構造であり, 内層は微細なさび粒子が密に凝集し $\mathrm{Cr}$ の濃化した $\alpha-\mathrm{FeOOH} に よ り$ 構成されていることが 明らかとなった。.したがって, 前述した $\alpha-\mathrm{FeOOH} の$ 増加にともなう腐食速度の低下は, 内層に $\alpha-\mathrm{FeOOH}$ が形成されるためであると言える.

長期暴露さび内層の最終安定さび層を構成する $\alpha$ -FeOOH の微視形態を透過型電子顕微鏡で観察した結 果, 特徴的なのは, 結晶粒径が数十 $\mathrm{nm}$ と極めて小さい ことである. 電子線回折パターンから同定される化合物 は， $\alpha-\mathrm{FeOOH}$ のみであることから, 安定さび層中の $\mathrm{Cr}$ は $\mathrm{Fe}$ の格子位置を一部置換していると考えられ,

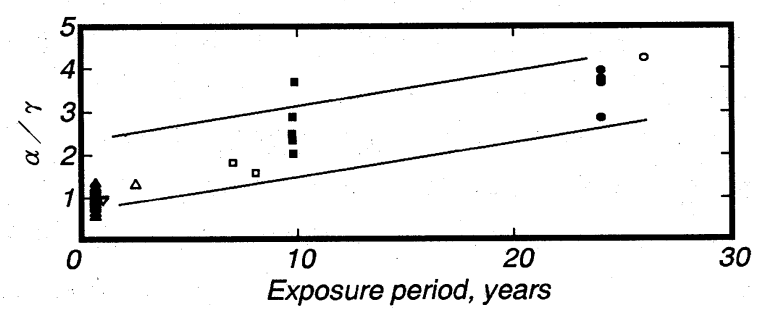

Fig. 5. The relation between the ratio of the amounts of $\alpha-\mathrm{FeOOH}$ and $\gamma-\mathrm{FeOOH}, \alpha / \gamma$, formed on low-alloy steels by atmospheric corrosion and the exposure period ${ }^{25}$.

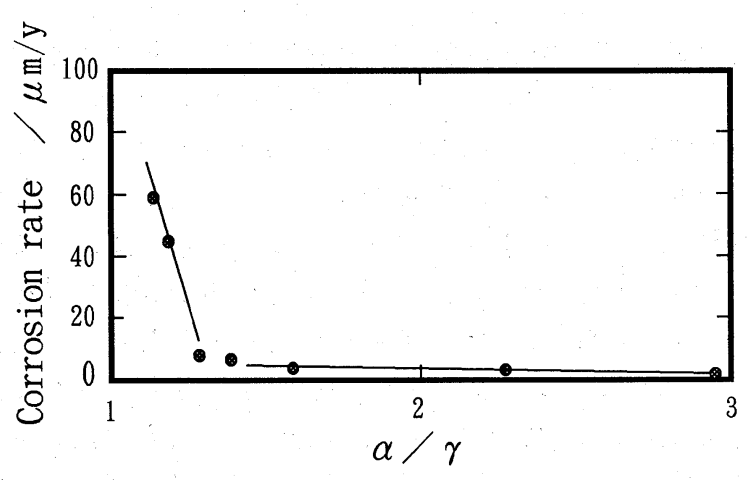

Fig. 6. The relation between the ratio of the amounts of $\alpha-\mathrm{FeOOH}$ and $\gamma-\mathrm{FeOOH}, \alpha / \gamma$, formed on low-alloy steels by atmospheric corrosion and the corrosion rate. 
最終安定さび層は $\alpha-\left(\mathrm{Fe}_{1-\mathrm{x}}, \mathrm{Cr}_{\mathrm{x}}\right) \mathrm{OOH}$ であると言える. 最終安定さび層の防食能力は微細な結晶が緻密に集合す ることによる環境遮断効果によるものと考えられる。こ の最終安定さび層中に含まれる $\mathrm{Cr}$ の効果は, $\alpha$ -FeOOH の結晶を微細化し密に凝集させることである と考えられている。 このことは $\mathrm{Cr}$ の鋼中添加量の増大 にともなうさび層防食性の向上が指摘されていることか らも支持される，また，最終安定さび層である $\alpha$ 相の $\mathrm{FeOOH}$ は, $\mathrm{FeOOH}$ の中でも熱力学的に最も安定であ り容易に還元されない. したがってさび層の還元による カソード反応の加速が生じにくく, 酸素と水の侵入が低 く抑えられた場合に鋼の腐食は極めて小さいものとなる.

以上のことより，耐候性鋼の耐食機構はさび層の相変 態に関連しており，暴露初期に形成するさび層から暴露 期間とともに X 線的非晶質物質を経由して最終的には 環境遮断性の高い緻密な内層の $\alpha-\left(\mathrm{Fe}_{1-\mathrm{x}}, \mathrm{Cr}_{\mathrm{x}}\right) 00 \mathrm{H}$ に 安定化すると考えられる。

\section{5 鉄文化財のさび}

鉄は古代より種々の用途に用いられているが，文化財 等として現代に受け継がれているそれら貴重な遺産のさ びを調査することは, 鉄鋼材料の長期耐久性を議論する 上で有益である.

鉄文化財の耐食性を示す事例にインドのクルッブミナ ール寺院に紀元前 $3 \sim 4$ 世紀の鉄の柱がある. 長期間使 用されているにもかかわらず，ほとんど腐食されていな いことで有名である. その理由としてデリーは乾燥して いる期間が長いことが最大の原因であると考えられてい るが，約 $0.114 \%$ の $\mathrm{P}$ を含んでいることも一因である。 鋼の耐候性向上に $\mathrm{P}$ が有効なことから，この柱がさび にくい理由は環境だけでなく，鋼質自身にもあると考え られる.

このように, 数 100 年, あるいは 1000 年を越えて存 在し続ける文化財の生命を理解することにより，現代の 金属および合金の数 100 年, 数 1000 年の酎久性を推定 することができ，また先人の生活様式を知る上でも重要 である。

長期間大気中において使用されていた文化財のさびの 解析結果の一例を泉屋博古館に保存されている中国製の 住友家鋳鉄獅子像について報告する。この鋳鉄獅子は今 から約 400 年前に明代の中国で作られたとされている.

鋳鉄獅子像のさびは，前述の耐候性鋼の場合と同様に主 に $\alpha-\mathrm{FeOOH}$ と $\gamma-\mathrm{FeOOH}$ から構成されていることが $\mathrm{X}$ 線回折により明らかとなった．鉄鋼材料の大気さび においては，暴露年数とともに $\alpha-\mathrm{FeOOH}$ の量が増加 する傾向にあることを前述した数十年間の耐候性鋼さび 層の解析結果より指摘したが，Fig. 7 に示すように約 400 年間大気中に暴露した鋳鉄獅子像のさびの多くは $\alpha$ -FeOOH により構成されており, 約 400 年もの長期間 を要してさびの相変態が進行し $\alpha-\mathrm{FeOOH}$ が主成分と なった。

次に，鉄文化財に生成したさび構成化合物を解析した 結果を, 前述の数十年間の大気暴露により形成された耐

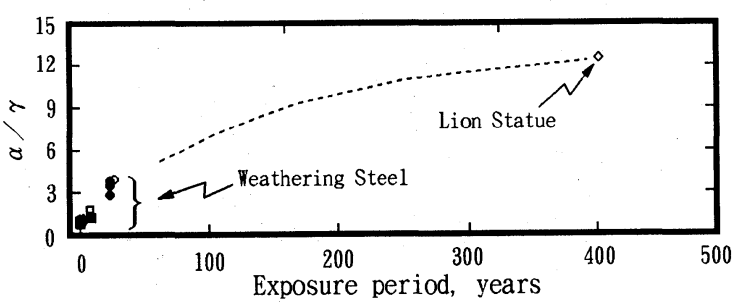

Fig. 7. The relation between the ratio of the amounts of $\alpha-\mathrm{FeOOH}$ and $\gamma-\mathrm{FeOOH}, \alpha / \gamma$, formed on low-alloy steels and the lion statue by atmospheric corrosion and the exposure period.

候性鋼さび層および 400 年間大気腐食環境に暴露された 鋳鉄製唐獅子像に形成されたさび層と比較しながら報告 する.

供試材は約 100〜1500 年前に製作された文化財である. それぞれについて判明している歴史を以下に示す.

〔記号 $\mathrm{ANCl}$ : 鉄刀のさび〕

1600 年前のもので，大垣市粉糠山古墳で 1981 年に, 同古墳後方部西よりのくびれ部に近い位置から採取. $20 \sim 30 \mathrm{~cm}$ の深さの土中に存在.

〔記号 ANC2 : 鉄鏃のさび〕

1400 年前のもので, 可児市川合稲荷塚 3 号墳古墳 玄室内, 鿬床上数 $\mathrm{cm}$ より出土. 石室内は流土が充 満していた．土質は黒色の粘土質であり，発見時に は地表下約 $1.5 \mathrm{~m}$ に存在.

〔記号 ANC 3 : 鉄鎚のさび`

1200 年前のもので，市原市荒久遺跡 302 号住居跡 の竪穴式住居の覆土中より出土。住居は台地上の関 東ローム層に堀込まれたもの. 表土下約 $50 \mathrm{~cm}$ と 考えられる。

〔記号 ANC 4 : ガス灯支柱のさび〕

100 年前 銀座の歩道に明治初期より設置.さびの 採取位置は，支柱基底部（地表下約 $40 \sim 50 \mathrm{~cm}$ ）の 内側.

いずれの供試材も，化学成分は不明であるが，このよう な古代に用いられた鉄文化財の化学成分はこれまでにい くつか調査されている。

Fig. 8 に示す X 線回折結果より，いずれのさびも主と して $\alpha-\mathrm{FeOOH}, \mathrm{Fe}_{3} \mathrm{O}_{4}, \gamma-\mathrm{FeOOH}$ から構成されてお り，さらに刀には $\beta-\mathrm{FeOOH}$ が，鏃および支柱には $\mathrm{SiO}_{2}$ が多ぐ認められる. 文化財さびは主に土中より発 掘されており，刀のさびに $\beta-\mathrm{FeOOH}$ が多く認められ たことにより，この刀は塩分の存在する環境にあったと 推測できる。 また，鏃および支柱に認められた $\mathrm{SiO}_{2}$ は 土の成分としてさび中に混入したと考えられる.

$\mathrm{X}$ 線回折 $\mathrm{KCl}$ 内部標準法を利用して，各さびの構成 化合物の定量を行った結果を以下に述べる.

(1) $\alpha / \gamma$ の経年変化 (Fig. 9)

前述したようにさびの性状評価の一つのパラメータで ある $\alpha / \gamma$ の経年変化は，大気暴露した耐候性鋼および 鋳鉄獅子のさびの場合（破線）に比較して，本文化財さ 


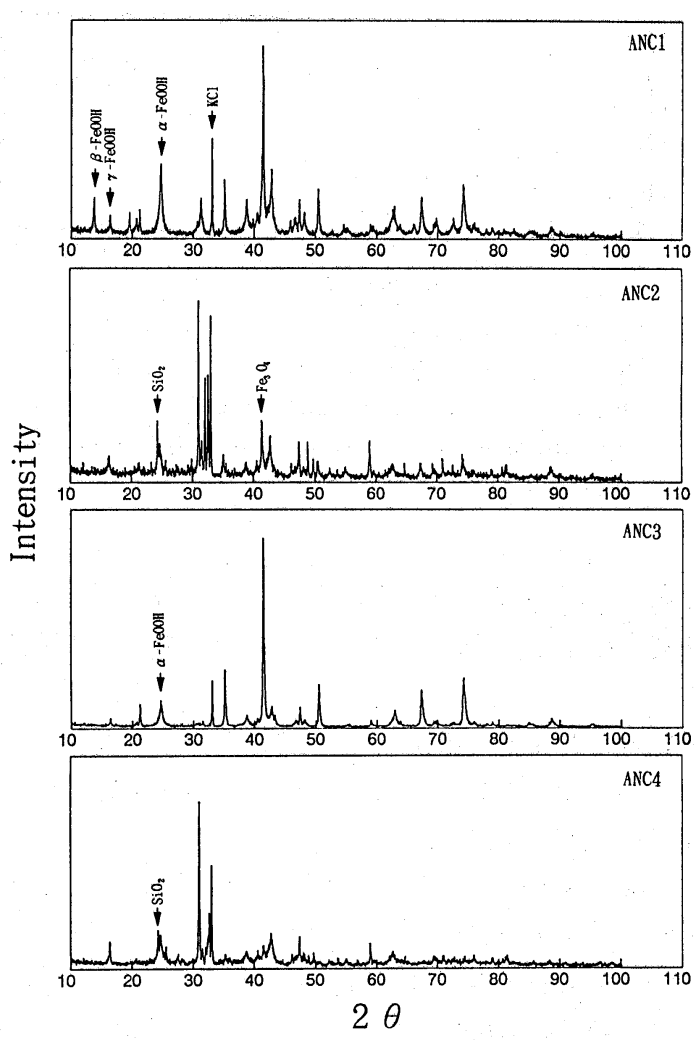

Fig. 8. X-ray diffraction patterns of the rust layers formed on the iron antiquities.

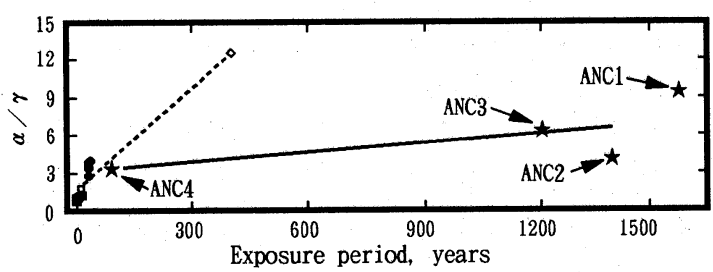

Fig. 9. The relation between the ratio of the amounts of $\alpha-\mathrm{FeOOH}$ and $\gamma-\mathrm{FeOOH}, \alpha / \gamma$, formed on low-alloy steels and the lion statue by atmospheric corrosion and on the iron an. tiquities, and the exposure period.

びの場合（ $\star$ 印: 実線）は増加速度が低い。この理由は 不明であるが，文化財さびが土中に長期間存在していた ことと関連があるとも考えられ，今後の検討が必要であ る.

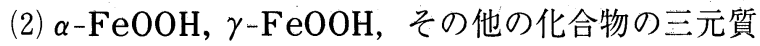
量比の経年変化 (Fig. 10)

大気暴露による耐候性鋼のさび層の構成化合物比は, $\mathrm{I} \rightarrow \mathrm{II} \rightarrow$ III の順に経年変化することが明らかとなってい るが，文化財さびは $\gamma-\mathrm{FeOOH}$ の少ない領域に位置す ることが特徴的である。なお $\alpha-\mathrm{FeOOH}, \gamma-\mathrm{FeOOH}$ 以 外の “その他の化合物” としては, 大気暴露によるさび 層中では主として X 線的非晶質物質であり，土中に保 存されていた文化財さびではさらに $\mathrm{Fe}_{3} \mathrm{O}_{4}, \beta-\mathrm{FeOOH}$, $\mathrm{SiO}_{2}$ が主なものとなる.

(3) $\alpha-\mathrm{FeOOH}, \gamma-\mathrm{FeOOH}, \mathrm{Fe}_{3} \mathrm{O}_{4}$ の三元質量比の経 年変化 (Fig. 11)

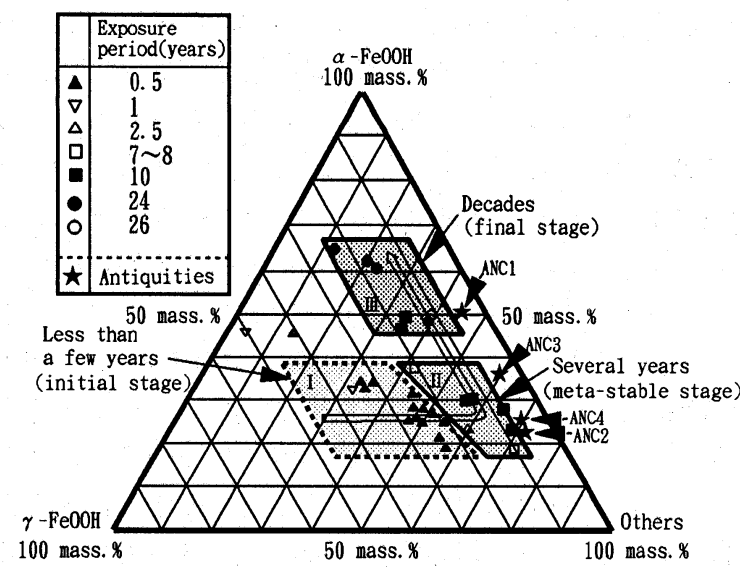

Fig. 10. The exposure-time dependence of the fractions of rust constituents formed on low-alloy steels by atmospheric corrosion and the iron antiquities.

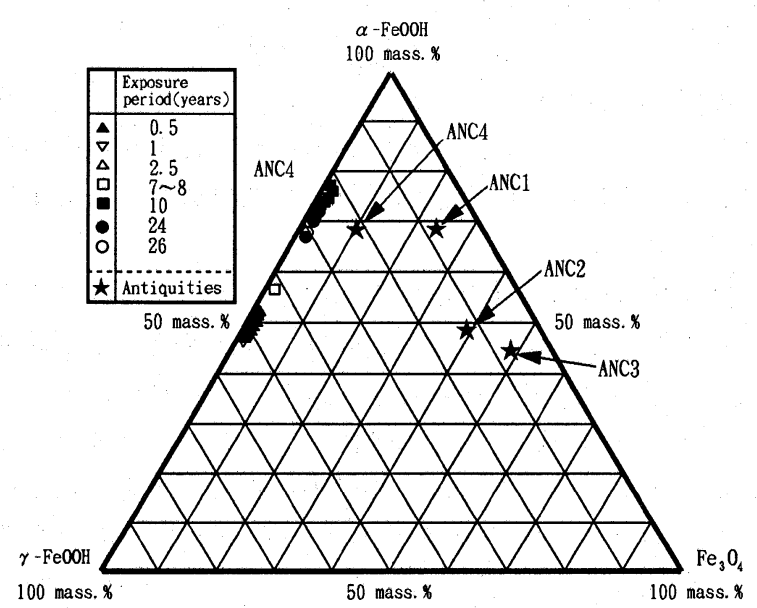

Fig. 11. The exposure-time dependence of the fractions of rust constituents formed on low-alloy steels by atmospheric corrosion and the iron antiquities.

数十年の大気暴露による耐候性鋼のさび層には, $\mathrm{Fe}_{3} \mathrm{O}_{4}$ がほとんど含まれていないため， $\alpha-\mathrm{FeOOH}-\gamma$ -FeOOH 線上にプロットされる. 一方，文化財さび中 に含有される $\gamma-\mathrm{FeOOH}$ が少ないため, 文化財さびは $\alpha-\mathrm{FeOOH}-\mathrm{Fe}_{3} \mathrm{O}_{4}$ 線上付近にプロットされる.

以上のように, 文化財さびについて得られたさび構成 化合物に関する結果は，大気暴露耐候性鋼のさび層に関 する知見と異なる。 この差異は，文化財さびが主として 土中に存在していたため, 大気中に存在する場合に比べ て酸素の供給が著しく少なく $\mathrm{Fe}_{3} \mathrm{O}_{4}$ が安定的に存在し ていることによると考えられる。 $\gamma-\mathrm{FeOOH}$ はより安 定な $\alpha-\mathrm{FeOOH}$ へほとんど相変態したため, 文化財さ びの主要結晶性構成物質は $\alpha-\mathrm{FeOOH}$ と $\mathrm{Fe}_{3} \mathrm{O}_{4}$ になっ ている. また，同様に土中に長期間存在していたさびの 中でも， $\beta-\mathrm{FeOOH}$ や $\mathrm{SiO}_{2}$ を特に多く含むものがあっ たことは注目すべきである，冒頭にも述べたように， $\beta$ -FeOOH は結晶格子中に $\mathrm{Cl}^{-}$を取り込むことにより安 定構造をとる。.したがって, $\beta-\mathrm{FeOOH}$ の存在は, 鉄 
文化財が海水や人々の生活廃棄物等より供給されたと推 定される塩分が豊富な環境に長期間存在していたことを 示唆するものである.このように，さびの構成化合物か ら鉄鋼材料の保存状態を推定することが可能となると言 えよう.

\section{6 結 言}

(1)大気中に暴露された鋼のさび層は，耐候性鋼につい

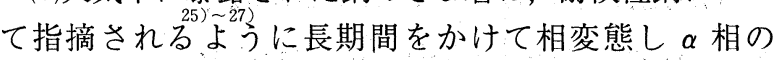
FeOOHに安定化する。

(2)鉄文化財さびは主として土中に存在していたため, 大気中に存在する場合に比べて酸素の供給が著しく少な く, $\mathrm{Fe}_{3} \mathrm{O}_{4}$ が安定的に存在している.

(3) $\beta-\mathrm{FeOOH}$ の存在は, 鉄文化財が海水や人々の生 活廃棄物等より供給されたと推定される塩分が豊富な環 境に長期間存在していたことを示唆するものである等, さびの構成化合物から鉄鋼材料の保存状態を推定するこ とが可能となる.

\section{参 考文 献}

1 ) S. T. Lennon and P. A. Robinson, Corros. Sci., 26, 995 (1986).

2) T: Misawa, Corros. Sci., 13, 659 (1973).

3 ）增子 昇, “自然環境での炭素鋼の腐食”, (1984) 東京大 学生産技術研究所.

4 ）三沢俊平，日本金属学会会報，24，201（1985）.

5 ）三沢俊平，防食技術，37，501（1983）.

6 ）杉本克久，日本金属学会会報，29，119（1990）.

7 ）増子 昇, “さびの扔はなし”，(1990）日本規格協会.

8 ）沢田正昭；平成 5 年度日本防錆技術協会関西支部記念講演 会資料, (1993).

9 ) T. Misawa, K. Asami, K. Hashimoto and S. Shimodaira, Corros. Sci., 14, 279 (1974).

10) M. Stratmann, K. Bohnenkamp and T. Ramchandran, Corros. Sci., 27, 905 (1987).

11) M. Stratmann and K. Hoffmann, Corros. Sci., 29, 1329 (1989).

12) J. Dünnwald and A. Otto, Corros. Sci., 29, 1167 (1989).

13) M. Stratmann and H. Streckel, Corros. Sci., 30, 697 (1990).
14) A. Cox and S. B. Lyon, Corros. Sci., 36, 1289 (1994).

15) S. Z. Zhang and S. B. Lyon, Corros. Sci., 36, 1309 (1994).

16）“防錆特別委員会, 鉄鋼材料の環境別, 用途別腐食度解説 図”，(1993）鋼材俱楽部

17）腐食防食協会編，“腐食技術便覧”，（1986）日刊工業新聞 社.

18）三沢俊平，橋本功二，下平三郎，防食技術，23，17 (1974).

19). T. Misawa, K. Asami, K. Hashimoto and S. Shimodaira, Corros. Sci., 14, 279 (1974).

20）三沢俊平，日本材料学会腐食防食部門委員会資料， 17, No.86, 1. (1978).

21) 岡田秀弥, 材料, 17, 705 (1968).

22）岡田秀弥, 細井祐三, 湯川憲一, 内藤浩光, 鉄と鋼, 55, 355 (1969).

23) H. Kihira, S. Ito and T. Murata, Corros. Sci., 31, 383 (1990).

24) J. T. Keiser and C. W. Brown, Corros. Sci., 23, 251 (1983).

25) M. Yamashita, H. Miyuki, Y. Matsuda, H. Nagano and T. Misawa, Corros. Sci., 36, 283 (1994).

26）三沢俊平，山下正人，松田恭司，幸 - 英昭，長野博夫，鉄 と鋼，79，69 (1993).

27）山下正人, 幸, 英昭, 長野博夫, 三沢俊平，材料と環境, 43, 26 (1994).

28) M. Yamashita, H. Nagano, F. Guillaume and R. A. Oriani, Materials Science Forum, 185, 515 (1995).

29) J. Keiser, C. Brown, R. H. Heidersbach and J. Electrochem. Soc., 129, 2686 (1982).

30）鉄獅子保存処理研究班, 泉屋博古館紀要, 9, 3 (1993).

31）岐皁県大垣市教育委員会編，“粉棣山古墳”, (1992).

32）長瀬治義, 可児市教育委員会編, “川合古墳群川合遺跡群”, (1994).

33）上総国分寺台遺跡調查団，市原市教育委員会編，“南向原”, (1976).

34）島根県教育委員会編，“出雲岡田山古墳”，(1987).

35）馬淵久夫, 富永 健, “続考古学のための化学 10 章”, （1986）東京大学出版会.

36）国立歴史民俗博物館研究報告第38集，（1992）国立歴史民 俗博物館.

37) U. Schwertmann and R. M. Cornell, "Iron Oxides in the Laboratory", (1991) VCH, Weinheim. 